\title{
A Preliminary Study on the Roles of Fe Content and Neoformed Ca-rich Minerals in the Coloration of Ceramic Glazes
}

\author{
Min Hye Lee, Min Su Han*, Ji Hye Kim \\ Department of Heritage Conservation and Restoration, Graduate School of Cultural Heritage, \\ Korea National University of Cultural Heritage, Buyeo 33115, Korea
}

Received August 4, 2020

Revised August 11, 2020

Accepted August 18, 2020

*Corresponding author

E-mail: dormer@nuch.ac.kr

Phone: +82-41-830-7381

Journal of Conservation Science 2020;36(4):275-283

https://doi.org/10.12654/JCS.2020. 36.4.05

pISSN: 1225-5459, eISSN: 2287-9781

(c) The Korean Society of Conservation Science for Cultural Heritage

This is an Open-Access article distributed under the terms of the Creative Commons Attribution Non-Commercial

License (http://creativecommons.org/ licenses/by-nc/3.0) which permits unrestricted non-commercial use, distribution, and reproduction in any medium, provided the original work is properly cited.
ABSTRACT Iron oxides are the essential coloring oxides in traditional ceramic glazes. However, when $\mathrm{Fe}$ is involved in the coloration in the form of ions or colloids in glazes with low $\mathrm{Fe}$ content, it is difficult to identify the iron oxide phases. Generally, in many these glazes, Ca-rich minerals are observed by X-ray diffraction (XRD) or microscopic images, owing to their devitrification by the high Ca content. This study attempts to elucidate the correlation between the crystalline structure and coloration in the glazes while mainly focusing on neoformed Ca-rich minerals and Fe content. An experimental firing was carried out to produce tree ash glazes, with pine tree ash and Buyeo feldspar. In the case of oxidation glazes, the scanning electron microscopy (SEM) images and XRD patterns did not exhibit any Ca-rich crystals, and all the visible light reflectance spectra lines exhibited a similar shape. In contrast, the reduction glazes divided into blue glazes and other colored glazes according to the shapes of their reflectance spectra. It was confirmed that the influence of Ca-rich minerals on the glaze color was more pronounced than the blue color of the reduction glazes when the $\mathrm{Ca}$ and feldspar contents were sufficiently high and low, respectively, to form wollastonite. As the $\mathrm{Ca}$ content increased and the elemental composition of the reduction glazes changed, the neoformation of the Ca-rich minerals, such as wollastonite, anorthite, diopside, and akermanite was sequentially observed.

Key Words Iron oxides, Colorant, Wollastonite, Anorthite, Diopside, Akermanite

\section{INTRODUCTION}

Iron oxides are the main constituents of traditional pigments and the most commonly used coloring oxides in ceramic glazes. Therefore, it is essential to elucidate their influence on the coloring mechanisms in traditional ceramics. The firing conditions, $\mathrm{Fe}$ content, and distribution of $\mathrm{Fe}$ in the glaze layers are the main factors that affect the glaze colors.

Glaze Colorations can be classified into three types using the Fe form (Hwang, 2008), i.e., ionic colorations (as in the celadon glaze), colloid colorations (as in the tenmoku glaze), and crystal colorations (as in the iron crystal glaze). Scientific analysis of the iron oxide phases during the coloring of a celadon glaze and iron glaze has been conducted using a Mössbauer spectrometer (Hwang, 2008; Jeon et al., 2011; Kim et al., 2010; Pyon, 2005). Raman spectroscopy analysis has also been carried out on Cheolwha Buncheong ware and blackware (Lim, 2013; Park, 2018). In previous studies, identifying the iron oxide minerals in the crystal structures was challenging when the iron oxides were in the form of ions or colloids during the coloration of the low Fe-containing glazes. In this case, a Ca-rich mineral was analyzed using X-ray diffraction (XRD), or microscopic images as they were devitrified by the high content of $\mathrm{Ca}$ in the glaze. The Ca-rich minerals are mostly produced during cooling after the highest temperature has been attained in the kiln. Anorthite, and rarely wollastonite, have 
been identified in the Goryeo celadon (Ham et al., 2002). Meanwhile, the XRD patterns obtained from the green celadon glaze of Gyeongseo- dong, Incheon, were assigned to diopside and augite (Lee and Cho, 2013).

The neoformed Ca-rich mineral type is considered to be related to the glaze material composition (Trindade et al., 2009). While the presence of $\mathrm{Fe}^{2+}$ and $\mathrm{Fe}^{3+}$ is already known to affect the UV-Vis light reflectance of the glaze layers, investigation on the role of both Ca-rich minerals and $\mathrm{Fe}$ in the coloration of traditional ceramic glazes are crucial.

As a preliminary study to this end, tree ash glazes, a traditional type of ceramic glaze, were produced in via firing. Only pine tree ash and Buyeo feldspar were used to manufacture the glazes to observe the changes in the composition ratio. The pine tree ash had a relatively high $\mathrm{Fe}$ content among other tree ashes; it was considered to be the main component of the celadon glazes. The Fe content was confirmed by analyzing the glaze materials in the specimens produced under condition-specific firing experiments. Based on the results, changes in the crystal structure and coloration were investigated.

\section{MATERIALS AND METHODS}

\subsection{Materials}

Two-component glaze materials were prepared at weight ratios of $2: 8,3: 7,4: 6,5: 5,6: 4$, and $7: 3$ and were fired in both oxidizing and reducing atmospheres (Table 1). The raw materials used in this study - pine tree ash (Pine Tree Ash, Dongyoung Ceramics, KOR) and Buyeo feldspar (Buyeo Feldspar, Daewon Ceramics, KOR)-were purchased from the domestic vendors. The ash were ball-milled to obtain a uniform maximum particle size of the glaze material. Only the particles passing through a 100 mesh sieve were used. An elutriation process was carried out to filter impurities, such as wood chips or charcoal scraps, and remove alkali components from the ash (Choi, 2016). Some of the untreated pine tree ash and elutriated ash were collected and used for analysis. Buyeo feldspar is the commercial name of feldspar from Buyeo feldspar mine, one of the leading domestic feldspar mines.
Table 1. Raw materials and firing conditions of the specimens

\begin{tabular}{ccccc}
\hline No. & Specimen & \multicolumn{2}{c}{ Weight $(\mathrm{g})$} & Fine tree \\
ash & $\begin{array}{c}\text { Buyeo } \\
\text { feldspar }\end{array}$ & condition \\
\hline 1 & O20 & 40 & 160 & \\
2 & O30 & 60 & 140 & \\
3 & O40 & 80 & 120 & $1270^{\circ} \mathrm{C}$, \\
4 & O50 & 100 & 100 & Oxidation \\
5 & O60 & 120 & 80 & \\
6 & O70 & 140 & 60 & \\
\hline 7 & R20 & 40 & 160 & \\
8 & R30 & 60 & 140 & \\
9 & R40 & 80 & 120 & $1250^{\circ} \mathrm{C}$, \\
10 & R50 & 100 & 100 & Reduction \\
11 & R60 & 120 & 80 & \\
12 & R70 & 140 & 60 & \\
\hline
\end{tabular}

* $\mathrm{O}$ or $\mathrm{R}$ refers to the firing atmosphere $(\mathrm{O}$ : Oxidizing, $\mathrm{R}$ : Reducing), the following number after the alphabetical character refers to the pine tree ash content (wt\%).

\subsection{Methods}

\subsubsection{Analysis of the glaze raw materials}

Elemental and crystal structure analyses were performed on the glaze raw materials. A quantitative analysis was performed on 10 main elements $(\mathrm{Si}, \mathrm{Al}, \mathrm{Fe}, \mathrm{Na}, \mathrm{Mg}, \mathrm{Ca}, \mathrm{K}$, Ti, P, and Mn) by the Korea Basic Science Institute, Seoul Center. A wave-dispersive X-ray fluorescence spectrometer (PW2404, Phillips, NLD) was used with an end window-type $\mathrm{X}$-ray tube rhodium anode operated at $60 \mathrm{kV}, 125 \mathrm{~mA}$. For the crystal structure analysis, an X-ray diffractometer (MiniFlex600, Rigaku, JPN) was used from $5^{\circ}$ to $80^{\circ}$ at a scan speed of $2 \%$ min and scan step of $0.02^{\circ}$.

\subsubsection{Experimental firing}

The firing was performed in electric furnace and gas kiln, and biscuit firing was achieved by initially heating the white porcelain soil to $400^{\circ} \mathrm{C}$ over 5 hours and then heating it further to $850^{\circ} \mathrm{C}$ over 4 hours.

During the oxidation firing, we used the temperature setting function of the electric furnace. The specimen was initially fired up to $900^{\circ} \mathrm{C}$ at heating rate of approximately $2.5^{\circ} \mathrm{C} / \mathrm{min}(6 \mathrm{~h})$, and then fired up to $1250^{\circ} \mathrm{C}$ at heating rate of approximately $1.46^{\circ} \mathrm{C} / \mathrm{min}(4 \mathrm{~h})$. Finally, it was fired up to $1270^{\circ} \mathrm{C}$ at heating rate of approximately $0.07^{\circ} \mathrm{C} / \mathrm{min}(5 \mathrm{~h})$; 
the temperature was maintained at this level for 3 hours or more. After the firing, the specimen was cooled to room temperature. The total firing time was more than 24 hours.

Meanwhile, during reduction firing, the specimen was initially fired up to $900^{\circ} \mathrm{C}$ at a heating rate of approximately $2.5^{\circ} \mathrm{C} / \mathrm{min}(6 \mathrm{~h})$ in the same method as the oxidation firing. Following this, a reducing agent (LPG gas) was introduced. Then, the specimen was fired up to a maximum temperature of $1250^{\circ} \mathrm{C}$ at a heating rate of approximately $1.46^{\circ} \mathrm{C} / \mathrm{min}(4 \mathrm{~h})$. However, the temperature was not maintained at the maximum temperature. The total firing time was more than 10 hours.

\subsubsection{Analysis of the fired specimens}

A portion of the glaze layer was collected before the firing and then ground using a mortar and pestle. Following this, the major elements analysis was performed using an energy dispersive spectrometer (X-Stream-2/micsF+, Oxford, GBR) attached to a scanning electron microscope (SEM) (EM30AX, Coxem, KOR). After the firing experiment, the color of the specimen was measured using a spectrophotometer (CR-700d, Minolta, JPN). Each specimen was mounted on epoxy resin and polished sequentially using polishers (Rotopol-11, Struers, DNK) and abrasive papers \#220, \#500, $\# 1200$, \#2400, and \#4000. The coloration properties of the processed cross-section of the glaze layer were observed using a metallurgical microscope (EPIPHOT200, Nikon, JPN). Meanwhile, the backscattering electron image obtained using SEM was observed after coating the specimen surface with gold. In addition, the main component of the crystals grown in the glaze layer was confirmed using SEM-EDS. To establish the glaze layer crystal structure, a diamond tip was mounted on a motor handpiece, and a portion of the glaze layer was collected and analyzed using an XRD analyzer. Some of the crystals observed on the cross-section were analyzed using a micro-Raman spectrometer (LabRam
ARAMIS, Horiba, FRA) using a laser line of wavelength 785 $\mathrm{nm}$ at $100 \times$ magnification.

\section{RESULTS}

\subsection{Analysis results for the glaze raw materials}

\subsubsection{Major elements analysis}

The major elements of the glaze raw materials were analyzed. Both pine tree ash samples were analyzed before and after sieving to determine any changes in the sample composition. As shown in Table 2, the Ca content of the untreated and elutriated samples were high at $33.3 \mathrm{wt} \%$ and $34.7 \mathrm{wt} \%$, respectively and the total contents of the 10 main elements was $94 \mathrm{wt} \%$. In addition, the loss-on-ignition (L.O.I) values were also high. The Fe contents of both pine tree ashes were $1.03 \mathrm{wt} \%$, showing the same value in the error range. The Buyeo feldspar had $76.8 \mathrm{wt} \% \mathrm{SiO}_{2}$ and $12.4 \mathrm{wt} \% \mathrm{Al}_{2} \mathrm{O}_{3}$, while the $\mathrm{Na}_{2} \mathrm{O}$ and $\mathrm{K}_{2} \mathrm{O}$ contents were similar.

\subsubsection{Crystal structure analysis}

The XRD patterns of the pine tree ashes showed peaks of calcite, lime, and quartz, while peaks of the clay minerals, such as muscovite and chlorite, were observed at angles $<12^{\circ}$ (Figure 1). Meanwhile, the arcanite $\left(\mathrm{K}_{2} \mathrm{SO}_{4}\right)$ peak with low intensities was confirmed in the untreated ash. The disappearance of the arcanite diffraction pattern corresponded with the decrease in the $\mathrm{K}_{2} \mathrm{O}$ content. It was assumed that some of the alkali components in the sample were removed during the elutriation process.

The XRD patterns of the Buyeo feldspar used in this study had dominant peaks of albite and quartz (Figure 2). Mica and microcline minerals were also identified. Pure albite has been reported as the main mineral in the Buyeo feldspar ore. The ore is typically characterized by a well-recrystallized mineral texture (Lee, 2008).

Table 2. Major elements of the pine tree ashes and Buyeo feldspar used in this study

\begin{tabular}{|c|c|c|c|c|c|c|c|c|c|c|c|c|c|}
\hline \multirow{2}{*}{\multicolumn{2}{|c|}{ Sample }} & \multicolumn{12}{|c|}{ Elemental composition (wt\%) } \\
\hline & & $\mathrm{Al}_{2} \mathrm{O}_{3}$ & $\mathrm{CaO}$ & $\mathrm{Fe}_{2} \mathrm{O}_{3}{ }^{*}$ & $\mathrm{~K}_{2} \mathrm{O}$ & $\mathrm{MgO}$ & $\mathrm{MnO}$ & $\mathrm{Na}_{2} \mathrm{O}$ & $\mathrm{P}_{2} \mathrm{O}_{5}$ & $\mathrm{SiO}_{2}$ & $\mathrm{TiO}_{2}$ & L.O.I & Total \\
\hline \multirow{2}{*}{$\begin{array}{c}\text { Pine tree } \\
\text { ash }\end{array}$} & untreated & 4.16 & 33.3 & 1.03 & 4.23 & 4.53 & 0.480 & 0.778 & 2.81 & 11.9 & 0.301 & 30.6 & 94.1 \\
\hline & treated & 4.09 & 34.7 & 1.03 & 2.30 & 4.66 & 0.471 & 0.922 & 2.98 & 11.9 & 0.330 & 30.9 & 94.3 \\
\hline \multicolumn{2}{|c|}{ Buyeo feldspar } & 12.4 & 0.479 & 0.155 & 3.74 & 0.008 & 0.020 & 3.82 & 0.007 & 76.8 & 0.022 & 0.72 & 98.1 \\
\hline
\end{tabular}

${ }^{*} \mathrm{Fe}_{2} \mathrm{O}_{3}=$ total $\mathrm{Fe}$ 


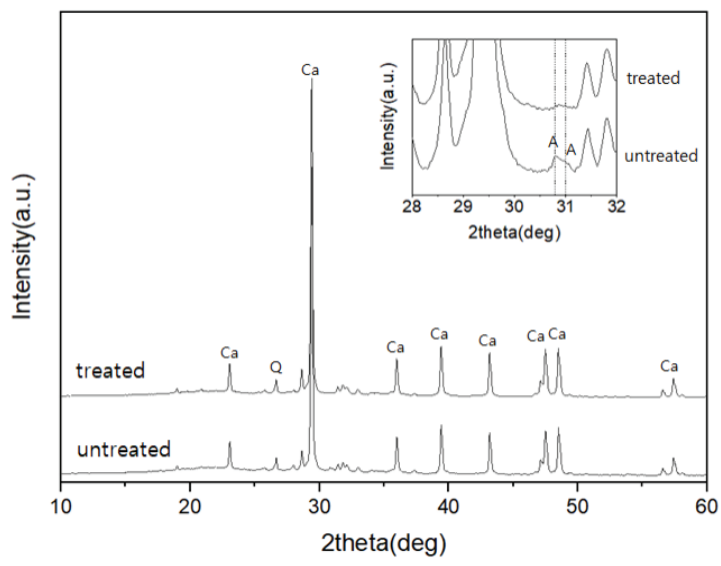

Figure 1. XRD patterns of the pine tree ashes before and after elutriation and sieving (Ca: $\mathrm{CaCO}_{3}$, Q: Quartz, A: Arcanite).

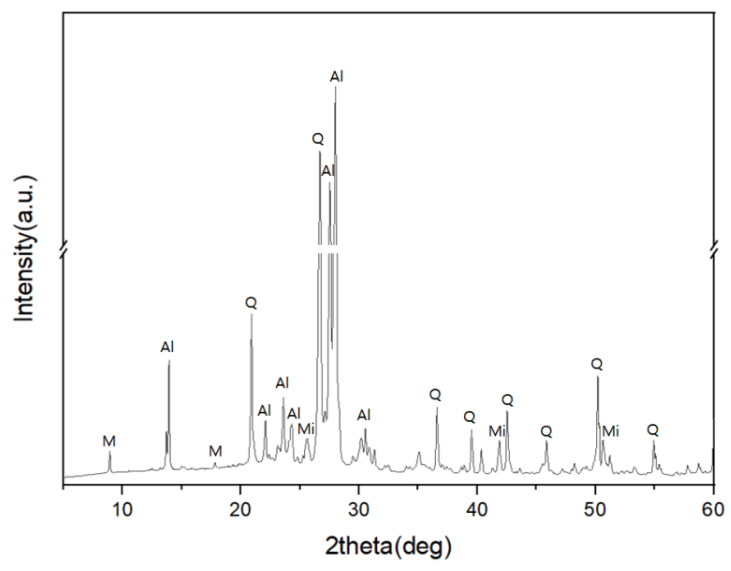

Figure 2. XRD pattern of the Buyeo feldspar (Al: Albite, Q: Quartz, M: Mica group, Mi: Microcline).

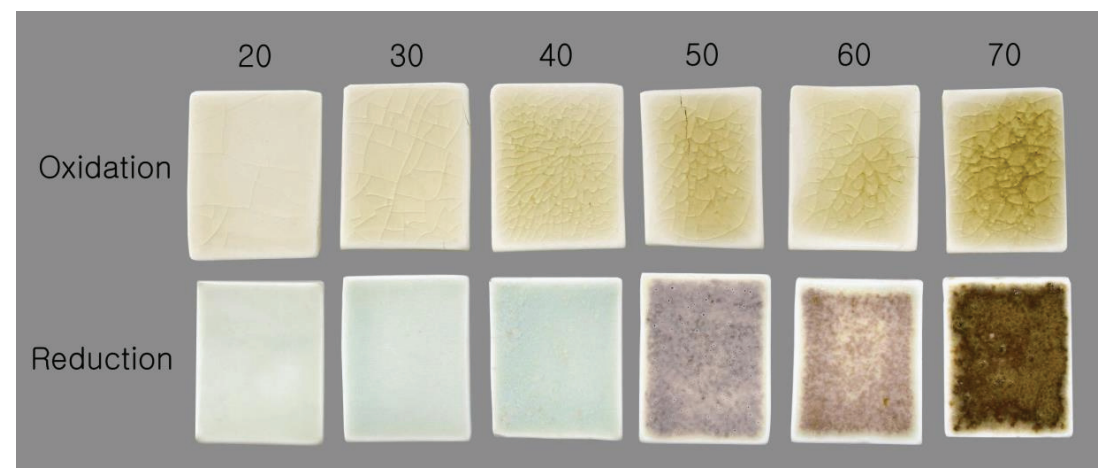

Figure 3. Fired specimens of different mixtures and firing atmospheres. The numbers above each specimen refer to the pine tree ash contents (wt\%).

\subsection{Analysis results for the fired specimens}

The characteristic coloration of the fired specimens depended on the content of the material used and the firing atmospheres (Figure 3). The oxidation glaze specimens were lustrous with a greenish-yellow appearance. The reduction glaze specimens R20, R30, and R40 were bright-blue in appearance, while R50, R60, and R70 differed in color. Meanwhile, crystals formed on the surface of the specimen R40 glaze. In addition, the devitrification of the glaze materials was observed in R50, R60, and R70.

\subsubsection{Major elements analysis}

As the pine tree ash content increased, the mixtures of glaze materials had higher $\mathrm{Ca}, \mathrm{Mg}, \mathrm{Fe}$ content, and lower $\mathrm{Si}$ and $\mathrm{Al}$ content than the Buyeo feldspar (Table 3). The Fe content tended to increase in the range of 0.34 to $0.67 \mathrm{wt} \%$, and the differences in each sample did not exceed $0.1 \mathrm{wt} \%$.

\subsubsection{Color measurement}

The oxidation glazes had low brightness levels and high degrees of yellowness as the pine tree ash content increased. Specimen O50 exhibited exceptional value, but the color difference after the experiment was not significant. The reflectance of the visible light region was high at around 600$700 \mathrm{~nm}$ (Figure 4). In the glazes subjected to a reducing atmosphere, a high pine tree ash content resulted in a lower brightness for all the specimens except R50. Meanwhile, the $a^{*}$ and $b^{*}$ values decreased from R20 to R40. From R50, the $a^{*}$ value became positive, while the $b^{*}$ value increased (Figure 6). The reflectance of the visible light region (Figure 5) had a similar spectrum in the case of the blue glazes R20, R30, and R40. It gradually decreased as it moved from the yellow to red regions; in the cases of R50 and R60. 
Table 3. Major elements of the glaze materials before firing

\begin{tabular}{cccccc}
\hline \multirow{2}{*}{ Specimen } & \multicolumn{5}{c}{ Elemental composition (wt\%) } \\
\cline { 2 - 6 } O20/R20 & 28.4 & 5.79 & 5.65 & 0.86 & 0.34 \\
\hline O30/R30 & 25.5 & 5.34 & 9.39 & 1.44 & 0.36 \\
\hline O40/R40 & 23.0 & 4.90 & 11.5 & 1.85 & 0.42 \\
\hline O50/R50 & 19.7 & 4.31 & 13.7 & 2.25 & 0.52 \\
\hline O60/R70 & 17.0 & 4.28 & 16.2 & 2.97 & 0.58 \\
\hline O70/R70 & 14.2 & 4.13 & 18.3 & 3.50 & 0.67 \\
\hline
\end{tabular}

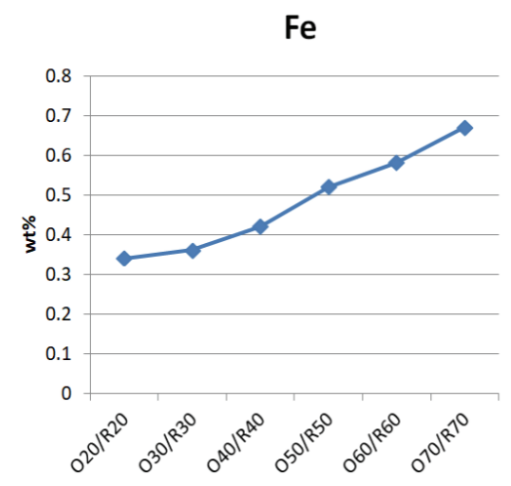

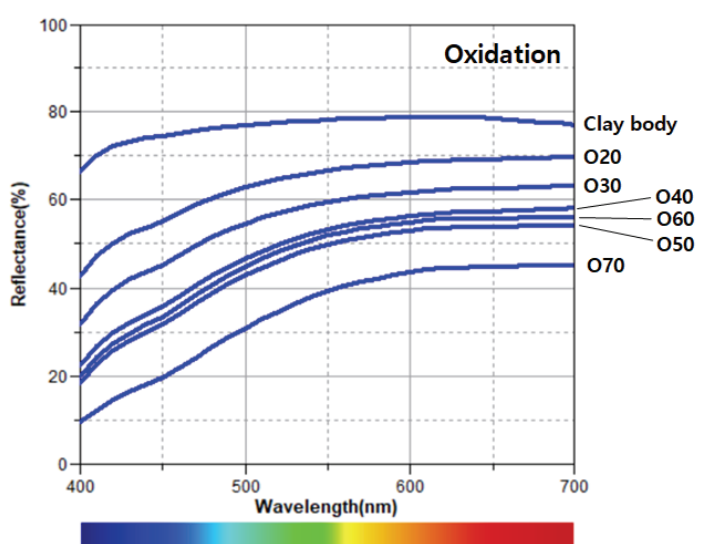

Figure 4. Reflectance spectra of the specimens fired in an oxidizing atmosphere.

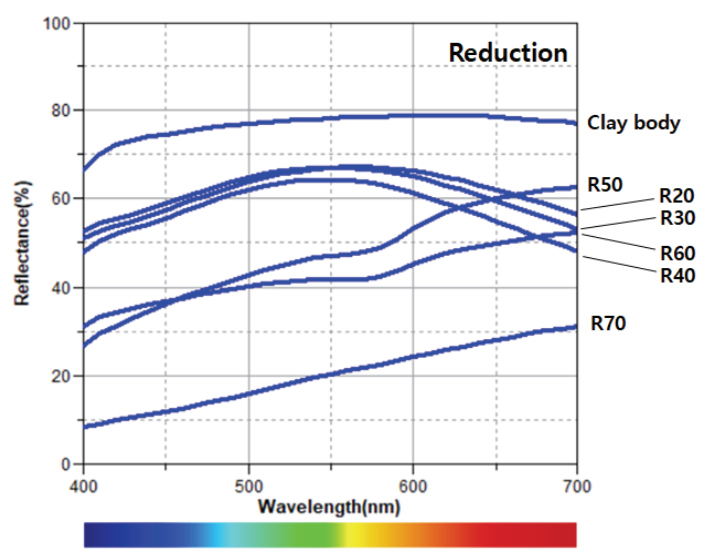

Figure 5. Reflectance spectra of the specimens fired in an reducing atmosphere.

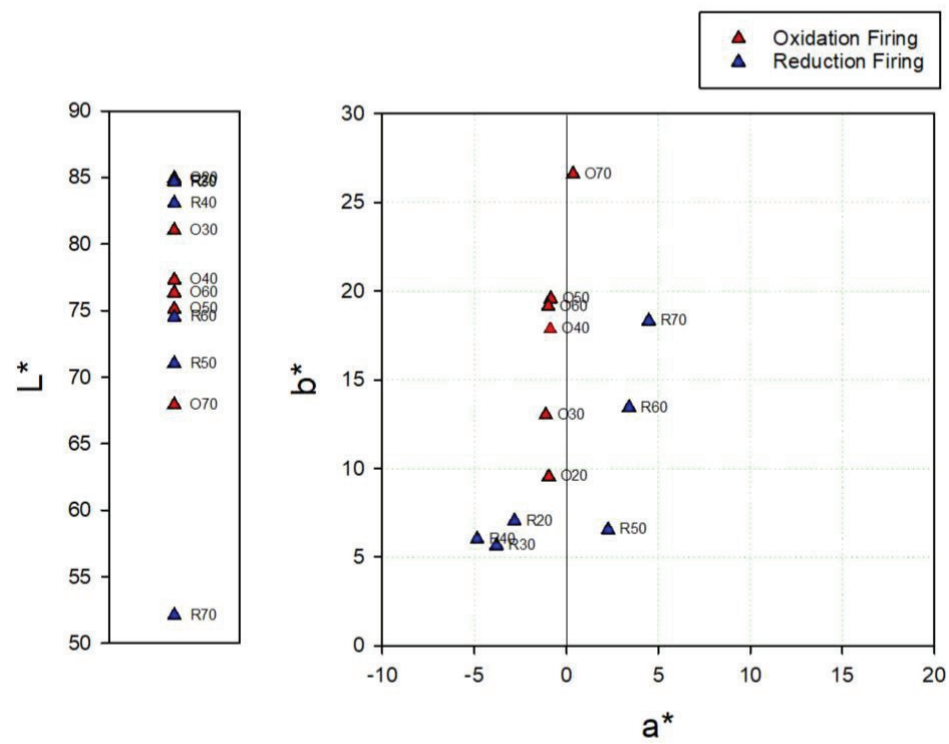

Figure 6. $\mathrm{L}^{*} \mathrm{a}^{*} \mathrm{~b}^{*}$ color coordinates of the fired specimens. 
Meanwhile, the reflectances appeared to increase rapidly around $570 \mathrm{~nm}$. Specimen R70 had a relatively low reflectance.

\subsubsection{Cross-sectional observation}

The cross-sectional observation results of the fired specimen are shown in Table 4. The thicknesses of the glaze layers increased, except for R60. This increase in thickness can be attributed to the differences in the viscosities when applied to the specimens. Meanwhile, spherical bubbles, which are generally produced in high-temperature fired glazes, were formed. As the pine tree ash content increased, the number of open bubbles shifting from the glazes to their outer surface layers increased. This was presumed to occur

Table 4. Cross-sectional image of the fired specimens observed using a metallurgical microscope and SEM

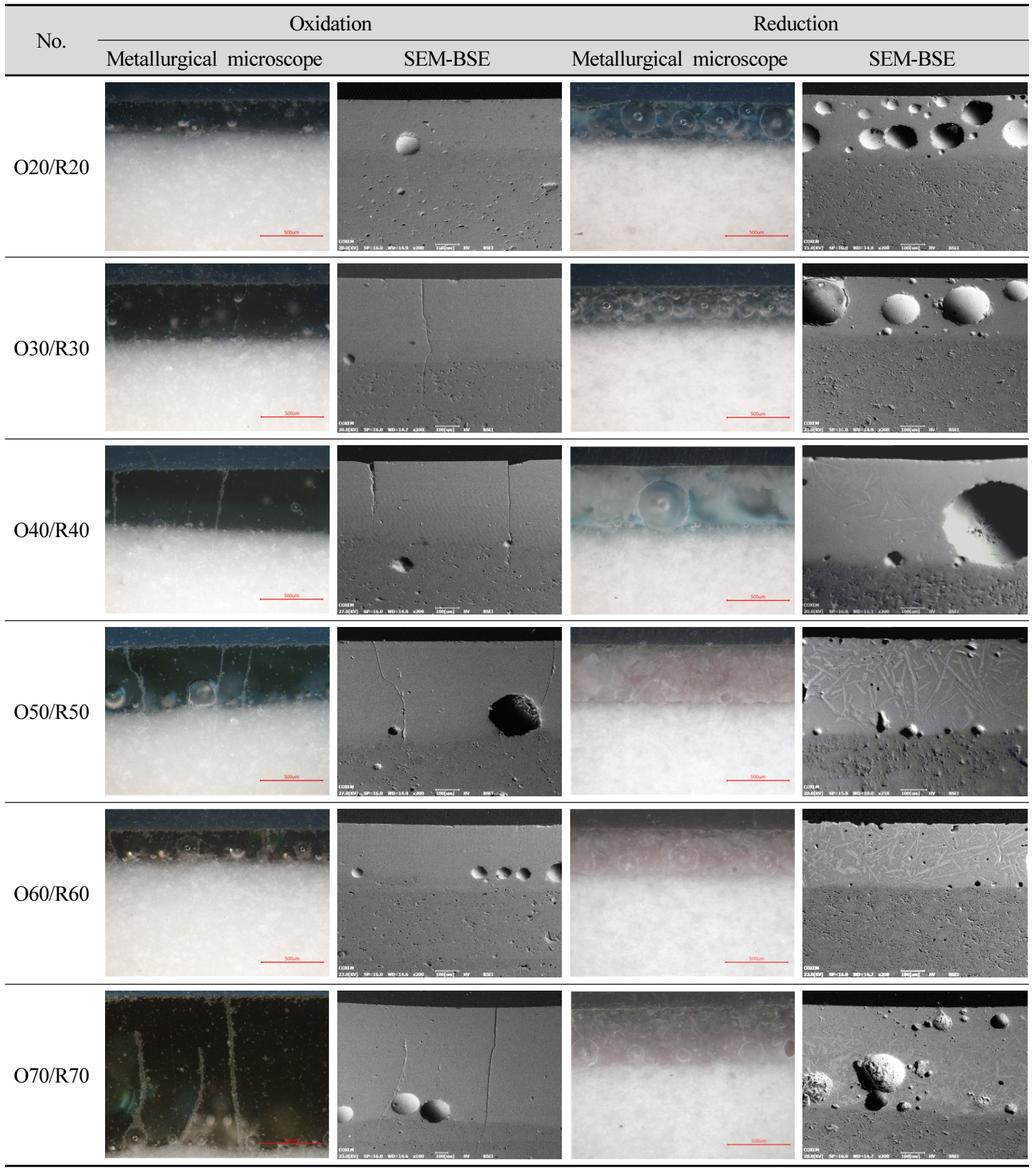



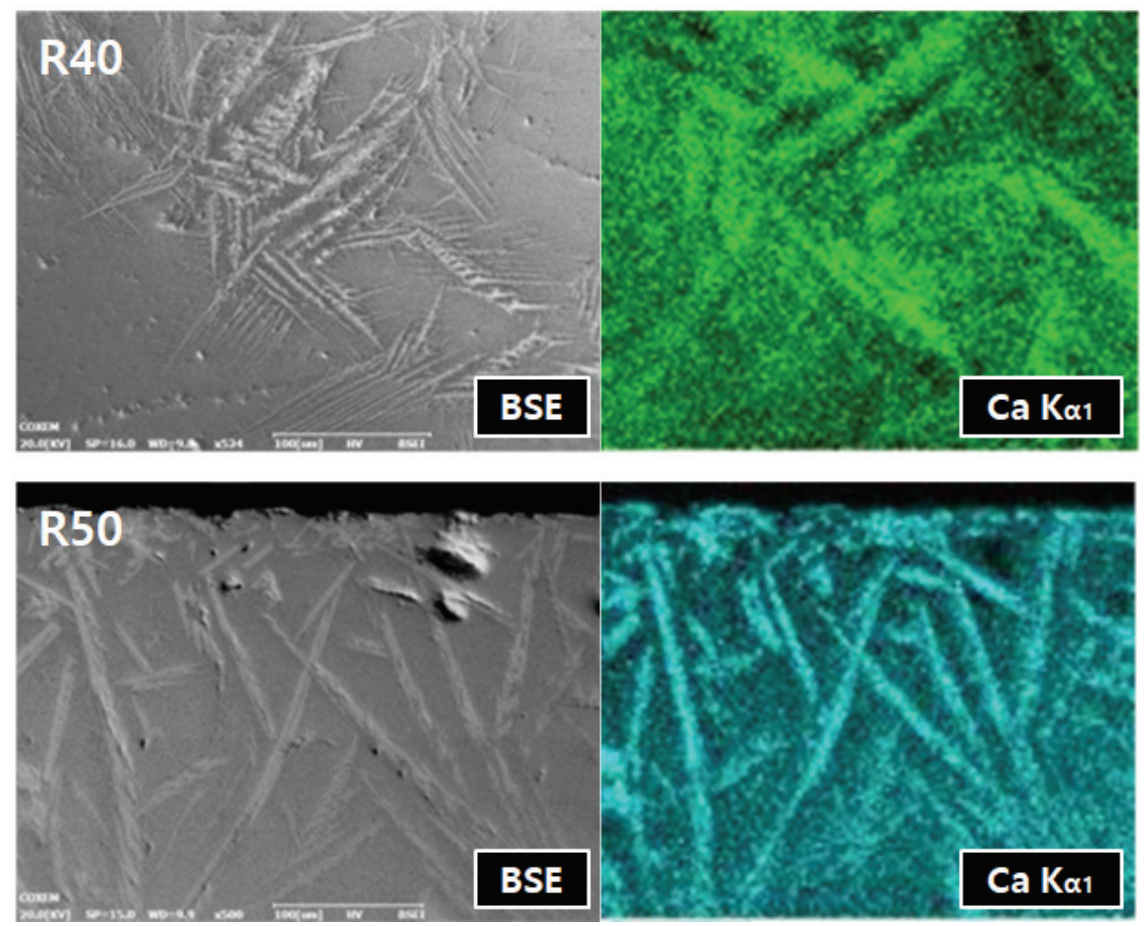

Figure 7. SEM-BSE images and Ca mapping results of specimens R40 and R50.

as the fluidity of the layer of the glazes increased. In the case of the specimens fired in a reducing atmosphere, R20 and R30, the bubbles that had not escaped the glaze layers were generally distributed over the glazes. However, the bubbles of R20 were large, while R30 had dense bubbles near the surface of the glaze layer. Meanwhile, crystal formation was confirmed in specimen R40. The surfaces of R50, R60, and R70 exhibited different colors, though their cross-sections were similar. However, the thickness of the brown layer near the surfaces gradually increased and the characteristic surface color appeared.

It was evident from the backscattered electron image produced using SEM that the glaze layers were divided into dark and bright layers according to the differences in their composition. As a result of the high-temperature firing, numerous spherical bubbles that could not escape from the glaze layers were identified. However, the size and shape of the bubbles were different, depending on the mixing ratio of the glaze materials. In the glazes subjected to a reducing atmosphere, needle-shaped crystals were observed in the specimens containing $40 \mathrm{wt} \%$ or more pine tree ash (Table 4). More of these crystals were produced as the pine tree ash content increased. The $\mathrm{Ca}$ content was high in the crystals, as shown by the element mapping using EDS (Figure 7).

\subsubsection{Crystal structure analysis}

Characteristic peaks of amorphous silica were identified from the crystalline structure analysis, with a broad hump between $15^{\circ}$ and $30^{\circ}$ in all the specimens (Figures 8 and 9). The diffraction peaks obtained from the specimens $\mathrm{O} 20$ and $\mathrm{O} 30$ were assigned to corundum $\left(\mathrm{Al}_{2} \mathrm{O}_{3}\right)$ (Figure 8). Meanwhile, devitrification occurred in specimens R40, R50, R60, and $\mathrm{R} 70$ as the $\mathrm{Ca}$ content increased in the reduction glazes (Figure 9). Wollastonite was also neoformed in specimens $\mathrm{R} 40, \mathrm{R} 50$, and $\mathrm{R} 60$. Anorthite $\left(\mathrm{CaAl}_{2} \mathrm{Si}_{2} \mathrm{O}_{8}\right)$ and diopside $\left(\mathrm{MgCaSi}_{2} \mathrm{O}_{6}\right)$ were abundant in $\mathrm{R} 50$ and $\mathrm{R} 60$, while akermanite $\left[\mathrm{Ca}_{2} \mathrm{Mg}\left(\mathrm{Si}_{2} \mathrm{O}_{7}\right)\right]$ was only found in $\mathrm{R} 70$, which had the highest $\mathrm{Mg}$ content. The peak intensity of the Ca-rich minerals increased as the pine tree ash content increased, as shown by the optical characteristics from the cross-sectional observations (Table 4, Figure 9).

In addition, Raman spectroscopy was carried out to confirm the variation in the R40 and R50 crystals, which changed the shape of the reflectance spectra. The Raman bands of $\beta$-wollastonite at $639 \mathrm{~cm}^{-1}$ and $973 \mathrm{~cm}^{-1}$ were identified (Figure 10A) (Carter et al., 2017), while mapping 


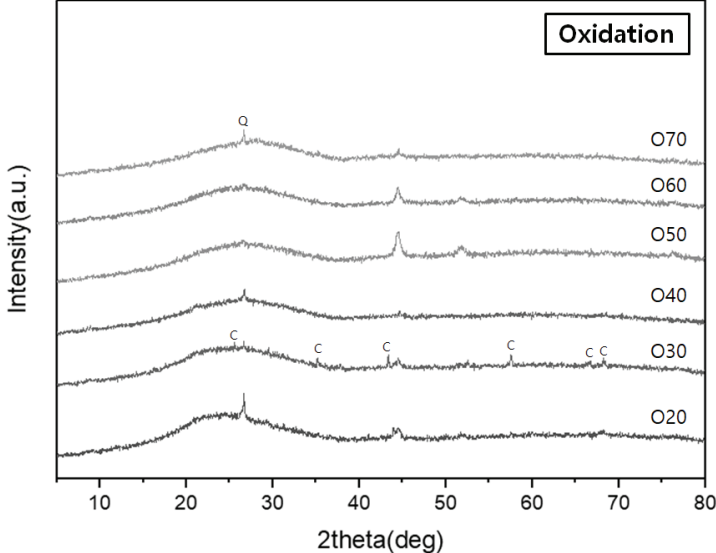

Figure 8. XRD patterns of the glaze layers of the specimens fired in an oxidizing atmosphere (Q: Quartz, C: Corundum).

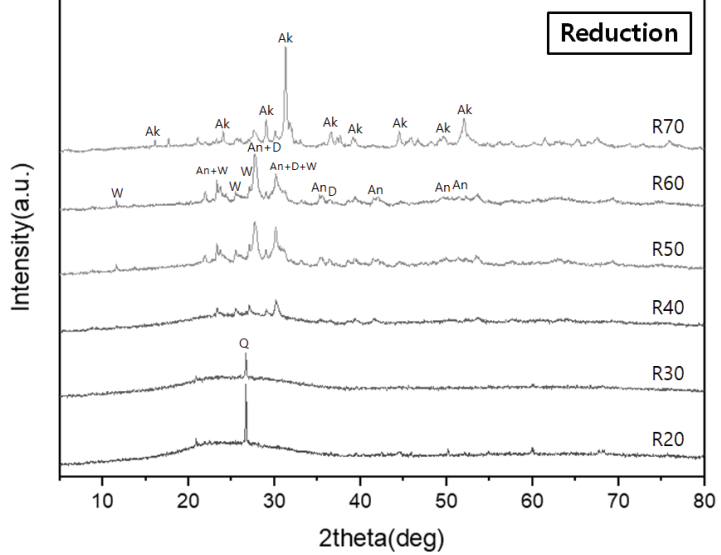

Figure 9. XRD patterns of the glaze layers of the specimens fired in a reducing atmosphere (Ak: Akermanite, An: Anorthite, D: Diopside, Q: Quartz, W: Wollastonite).
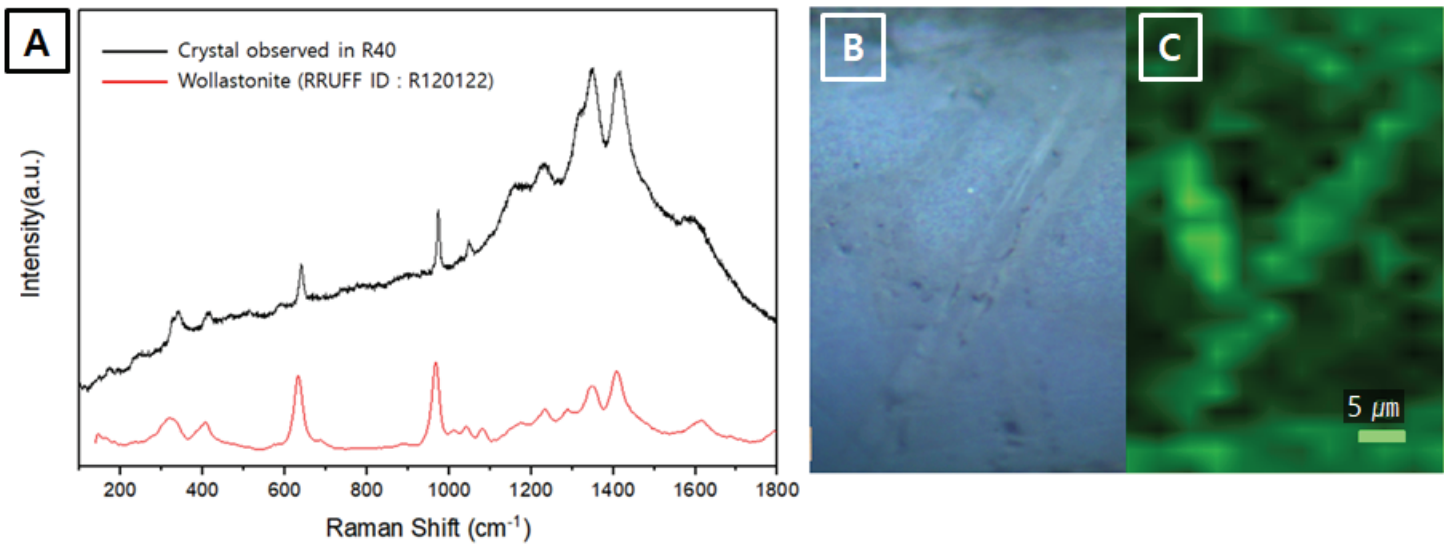

Figure 10. Raman analysis results of specimen R40. (A) Raman scattering spectrum of the needle-shaped crystal excited by a $785 \mathrm{~nm}$ laser line, (B) Optical microscope image of the mapping area, (C) Raman mapping of the Si-O bridging stretching peak of wollastonite.

using the Si-O bridging stretching band near $639 \mathrm{~cm}^{-1}$ enabled the visualization of the crystal shapes (Figure 10B and $10 \mathrm{C})$.

Wollastonite is produced by the following reaction in glazes with abundant $\mathrm{CaCO}_{3}$ and $\mathrm{SiO}_{2}$ :

$$
\mathrm{CaCO}_{3}+\mathrm{SiO}_{2} \rightarrow \mathrm{CaSiO}_{3} \text { (wollastonite) }+\mathrm{CO}_{2}
$$

It generally becomes unstable in the presence of $\mathrm{SiO}_{2}$ and they react to produce anorthite (Trindade et al., 2009).

However, as shown by the XRD patterns (Figure 9), wollastonite maintained its structure in the glazes of specimens R40, R50, and R60.

\section{DISCUSSION AND CONCLUSION}

The coloration characteristics of the glazes varied depending on the experimental conditions. The fired specimens showed distinct coloration changes, and the overall reflectances of the visible light decreased as the pine tree ash content increased. while the iron oxide minerals were not identified, the specimens with similar variations in the visible light reflectance spectra showed similar crystal structures.

The SEM images and XRD patterns of oxidation glazes did not show any Ca-rich crystals and all the reflectance spectra lines had a similar shape. In contrast, the reduction glazes were clearly divided into different shapes of the 
reflecance spectra; the blue glazes up to R40 that rarely devitrify Ca-rich minerals, compared with other colored glazes. In particular, the visible light reflectance of the glazes in the regions over $570 \mathrm{~nm}$ increased as the Ca-rich minerals appeared as needle-shaped crystals at the cross-section. The $\mathrm{Fe}^{3+}$ in the iron oxide contained in the oxidation glazes was opaque yellow, while the $\mathrm{Fe}^{2+}$ appeared as clear-blue in the celadon (Hwang, 2008). Basically, the coloration of the traditional ceramics is closely related to the oxidation state of iron. However, these results confirmed that the influence of Ca-rich minerals on the glaze color was more pronounced than the blue color of reduction glazes when $\mathrm{Ca}$ and feldspar contents were sufficiently high and low to form wollastonite.

It was reaffirmed that iron affects the coloration of the ceramic glaze layer under various conditions. Iron could also be involved not only with iron oxide crystals, such as hematite or magnetite, but also in the coloration with neoformed Ca-rich minerals. Consequently, the optical properties of ceramic glazes are closely related to the neoformed minerals produced under various conditions, such as firing temperature, atmosphere, and $\mathrm{CaO}, \mathrm{MgO}, \mathrm{Al}_{2} \mathrm{O}_{3}$, and $\mathrm{SiO}_{2}$ content. To clearly establish the correlation between the neoformed Ca-rich minerals and ion color of $\mathrm{Fe}$ in traditional ceramics, further studies on the locally excavated ceramics, experimental firing, and analysis of the glazes with higher Fe content are essential.

\section{ACKNOWLEDGEMENTS}

This paper was performed with support from 「2019 Academic Research Project by Korea National University of Cultural Heritage $\lrcorner$.

\section{REFERENCES}

Carter, E.A., Wood, M.L., de Waal, D. and Edwards, H.G.M., 2017, Porcelain shards from Portuguese wrecks: Raman spectroscopic analysis of marine archaeological ceramics. Heritage Science, 5(17).

Choi, Y.D., 2016, A convergence study on the ash glaze manufacturing process - Analysis of $\mathrm{pH}$ changes appearing in the ash glaze elutriation process. Korea Science \& Art Forum, 25, 427-438. (in Korean with English abstract)
Ham, S.W., Shim, I.W., Lee, Y.E., Kang, J.Y. and Koh, K.S., 2002, An archaeological microstructural study on Koryo inlaid celadon. Bulletin of the Korean Chemical Society, 23(11), 1531-1540.

Hwang, C.O., 2008, A study on the effects of $\mathrm{Fe}^{2+}$ and $\mathrm{Fe}^{3+}$ on the iron glaze coloring. Master's thesis, Myongji University, Seoul, 43-49. (in Korean with English abstract)

Jeon, A.Y., No, H.G., Kim, U.S., Cho, W.S., Kim, K.J., Kim, J.Y., Kim, C.M., Kim, C.S. and Kang, G.I., 2011, Systematic study on colorative mechanism of ancient Goryeo celadon glaze by mossbauer spectroscopy and chromaticity analysis. Journal of the Korean Ceramic Society, 49(1), 66-71. (in Korean with English abstract)

Kim, J.Y., No, H.G., Jeon, A.Y., Kim, U.S., Cho, W.S., Kim, K.J., Kim, C.M. and Kim C.S., 2010, Mössbauer spectroscopic study on colorative mechanism of celadon glaze. Journal of the Korean Ceramic Society, 48(1), 34-39. (in Korean with English abstract)

Lee, H.Y., 2008, Type and origin of the domestic leading feldspar mines: Jecheon and Buyeo mine. Journal of the Korean Earth Science Society, 29(7), 640-644. (in Korean with English abstract)

Lee, S.W. and Cho, I.M., 2013, Study on clay and glaze ingredient analysis of Incheon Gyeongseodong green celadon. The Journal of the Korean Society of Ceramic Art, 10(2), 103-116. (in Korean with English abstract)

Lim, S.H., 2013, Development of black pigment and physical property enhancement for Geryong Mountain Buncheong ware on the basis of analysis of Chulwha pieces. Doctoral dissertation, Myongji University, Seoul, 30-34. (in Korean with English abstract)

Park, J.H., 2018, A study on the changing properties of iron oxides in black glazes using Raman microscope: Focused on black glazes excavated in Shinan shipwreck. Master's thesis, Korea National University of Cultural Heritage, Buyeo, 37-52. (in Korean with English abstract)

Pyon, K.R., 2005, A Study on the Coloration of Iron Glazes by Red Clay and Natural Stone. The Journal of the Korean Society of Ceramic Art, 1, 103-116. (in Korean with English abstract)

Trindade, M.J., Dias, M.I., Coroado, J. and Rocha, F., 2009, Mineralogical transformations of calcareous rich clays with firing: A comparative study between calcite and dolomite rich clays from Algarve, Portugal. Applied Clay Science, 42, 345-355. 